\title{
17 Years of Stirring History
}

\section{Shows International Exchange of Ideas}

\author{
by Eric G. Malmlow
}

$\mathrm{T}$ $\mathrm{HE}$ development of the induction stirrer started in Sweden in 1936. Dr. Ludwig Dreyfus of the Swedish Electric Co., ASEA, studied the problem of whether the bath in a hot metal mixer could be stirred by some electrical method. He suggested a solution and demonstrated that his principle would work, but the project was abandoned.

It was not until 1939 that a full-scale electric stirrer was constructed. It was tested on a 15-ton arc furnace at Surahammars Bruks AB. Because of the furnace construction, the stirrer had to be placed inside the furnace shell on top of the bottom plate. As a consequence the stirrer was soon damaged mechanically. This experience proved that the electric stirrer must be placed outside the furnace in order to accomplish its purpose under the conditions prevailing in a steel mill.

Investigation showed that a furnace bottom plate made of austenitic steel would permit the passage of an alternating magnetic flux without causing prohibitive eddy current loss. The magnetic flux after penetrating the bottom plate still retained sufficient density to reach the melt through the refractory lining and exert enough force to produce the desired stirring action.

After these fundamental features of the electric stirrer had been demonstrated, the first commercial ASEA induction stirrer was put in operation in the fall of 1947 on a 15-ton furnace at the Hagfors Steelworks, Uddeholm AB. Shortly afterward, in June 1948, a new 12-ton furnace provided with an induction stirrer was put into operation at Surahammars Bruks AB. The principal of the ASEA induction stirrer and the metallurgical results obtained at Hagfors and Surahammar during 11/2 years in service were presented in Sweden in May 1949., ${ }^{1,3}$ The metallurgical results were also discussed before the AIME Electric Furnace Steel Conference in Pittsburgh in 1949.

Since that time, the acceptance of the induction stirrer has been rapid. In Sweden four other steel companies have installed induction stirrers. Stirrers are also to be installed in Spain, France, and Belgium, the last mentioned on a 24-ft furnace. In the United States, one huge induction stirrer has been in operation for more than a year at the Timken Roller Bearing Co. This stirrer, with its converter set, was manufactured in the United States by the Elliott Co. in accordance with ASEA's designs and patents. ${ }^{5}$

E. G. MALMLOW is President, Aros Electric Inc., New York. This article is an abstract of the paper presented at the AIME Electric Furnace Steel Conference, Cincinnati, Dec. 2 to 4, 1953.
This was arranged with Aros Electric Inc. which is a wholly owned subsidiary of ASEA (Allmanna Venska Elektriska Aktiebolaget) and represents the Swedish company in the United States.

The application of induction stirrers requires that the bottom of the furnace shell above the stirrer be made of nonmagnetic material having high electric resistivity. This feature is introduced at least expense when the furnace is first constructed or is being rebuilt for some additional reason. The adaption of existing furnaces as well as new ones, with flat or with dished bottoms, is relatively simple because of the development of the highly efficient, static ASEA stirrer. This induction stirrer requires little space under the furnace because of its close concentration of the magnetic flux to the very area above the unit itself.

Induction stirrers have given excellent results and satisfaction to the users, and the economical, metallurgical, and operational advantages ${ }^{6}$ of the stirrer warrant close examination by those responsible for the production of quality electric furnace steel. In view of past developments it seems that the time is near when the induction stirrer will be considered an indispensable component of the electric arc furnace whenever quality steel is produced. But the advantages gained with the use of the stirrer have proved it to be economical even when lower grades of steel are made. This trend may gain momentum as more experience is obtained.

It also seems reasonable to anticipate the application of induction stirring to mixers and to open hearth furnaces with special problems. Opportunities can also be found in other industries. In the production of ferroalloys, for instance, the same principles apply. So far, no such applications have been decided upon, but the possibilities do exist.

\section{References}

${ }^{1}$ L. Dreyfus: Inductive Stirring in Arc Furnaces. Electrotechnical Aspects. Jernkontorets Annaler (1949) 133, p. 371.

${ }^{2}$ L. Dreyfus: An Induction Stirrer for Arc Furnaces. ASEA Journal (1950) 23, p. 46.

${ }^{3} \mathrm{~F}$. Nilsson: Induction Stirring in Arc Furnaces. Metallurgical Aspects. Jernkontorets Annaler (1949) 133, p. 385 .

${ }^{4}$ S. Fornander and F. Nilsson: Inductive Stirring in Arc Furnaces. Journal of Metals (Jan., Feb. 1950) 188, p. 22 , p. 256

${ }^{5}$ U. S. Patent Nos. 2,256,518; 2,513,082; 2,620,366; and $2,573,319$.

${ }^{\circ}$ P. E. Hammarlund: Induction Stirrers for Arc Furnaces. III ${ }^{\mathbf{e}}$ Congres International d'Electothermie (1953) Sec. 1, No. 110. 